\title{
Employee Engagement, Organisational Commitment and Performance of Selected State Corporations in Kenya
}

\author{
Stephen G. Cheche, PhD Candidate \\ Kenyatta University, Kenya \\ Stephen M.A. Muathe, PhD \\ Samuel M. Maina, PhD \\ School of Business, Kenyatta University, Kenya
}

Doi: 10.19044/esj.2017.v13n31p317 URL:http://dx.doi.org/10.19044/esj.2017.v13n31p317

\begin{abstract}
The influence of employee engagement on organisational performance has been widely acknowledged and confirmed. However, there are scanty empirical investigations on the mediating role of organisational commitment on the relationship between employee engagement and organisational performance. Therefore, this study sought to investigate the mediating influence of organisational commitment on the relationship between employee engagement and performance of selected state corporations in Kenya. The study adopted a positivistic approach to investigate the relationships among and between the variables. Descriptive and explanatory research designs were used to describe the variables and establish the nature of the relationships among them. The study is based on employees of state corporations in research and training in the republic of Kenya. A sample of 378 respondents was selected using a multi stage sampling strategy. Data was analysed using descriptive and inferential statistics. The result indicates that employee engagement influences organisational performance and that the relationship is partially moderated by organisational commitment.
\end{abstract}

Keywords: Employee engagement, organizational commitment, performance of state corporations

\section{Introduction}

State corporations have been identified as important drivers in accelerating national growth and development as well as improving delivery of public services (RoK, 1965; Anastassiou \& Doumpos, 2000). However, their performance has over the years been a matter of public concern (Obong'o, 2009). This has resulted in enormous pressure to improve service 
delivery, lower cost and become more accountable to taxpayers (Metawie \& Gilman, 2005). To meet increased demand for efficient use of tax revenue, most governments in the world have responded with introduction of public service reforms. Most of the reforms have however involved adoption of private sector practices in to the public service which has led to commodification of services and to some extent reduced professionalism of workers (Adcroft \& Willis, 2005).

In Kenya, the government initiated various reforms such as divesture, retrenchment, privatisation, and strategic partnership with private investors and performance contracting (Kobia \& Mohammed, 2006). Indeed the country is one of the few countries in Africa to implement comprehensive public service reforms (Economic Commission for Africa, 2010). However, progress has been hindered by partly by inability to hire and retain the right calibre of staff as well and poor and wrong diagnosis and prognosis (ECA, 2010; RoK, 2013).

The increased demand for quality services against non-increasing resources has ensured that efforts to improve performance of state corporations continue to occupy a central place within government policy and the public discourse. Indeed in 2013, the Government of Kenya appointment a task force to advice on how to improve performance of state corporations (RoK, 2013). However the focus of the various strategies undertaken to improve performance have mostly focussed on institutional and structural reforms while scarcely addressing critical issues such as employee engagement even though there is overwhelming empirical evidence demonstrating that it is correlated to organisational outcomes (Smith \& Markwick, 2009; Albrecht, Bakker, Gruman, Macey \& Saks, 2015). In an ever changing business environment, a committed and proactive work force could provide organisations with competitive advantage (Bakker, Schaufeli, Leiter \& Taris, 2008).

The correlation between employee engagement and organisational performance has however been found to be weak partly because engagement does not affect organisational performance directly but do so through other variable that predict performance (Chughtai, 2008). Therefore, this study sought to investigate the mediating role of organisational commitment on the relationship between employee engagement and performance of selected state corporations in Kenya.

\section{Literature Review}

This section presents theoretical and empirical review of related literature while identifying the gaps that this study seeks to address 


\section{Theoretical Review}

The Social exchange theory (SET) is among the most influential theories for understanding work place behaviour (Croponzano \& Mitchell, 2005) and has its roots in anthropology. It is however Blaus (1964) who is credited as its founder (Robbins, 1991).The theory has been progressed by other researchers such as; Das and Teng (2002); Globerman and Nielsen (2007).

Blaus (1964) posited that individuals voluntarily behave in certain ways or do certain things because they expect positive reciprocal behaviour from others. Social exchange is based on trusting others to reciprocate. Human beings in social situations choose behaviour that maximises their likelihood of meeting self-interests.

Critics of social exchange theory have pointed out its weakness as the assumption that people are rational and will always act in rational ways. In reality however, people sometimes act in irrational ways. Caution should therefore be exercised when applying the theory to workplace environment. However, the social exchange theory is a useful model in advancing studies on employee engagement due to its focus on reciprocal relationship between employer and employees and hence was used as the anchor theory in this study.

\section{Empirical Review}

This part presents a critical review of previous empirical studies related to the variables of the study

\section{Employee Engagement and Organisational Performance}

Employee engagement have been found to have an impact on critical business success factors such as customer satisfaction, employee turnover, employee commitments and other related constructs which in turn affects organisational performance (Right Management, 2009). Most employers also believe that engaged employees are willing to do more, have higher productivity and positive work relationships (Psychometric Canada, 2011). These two surveys were conducted in developed economies and it is imperative that further research be carried out in a different set up to establish whether the findings hold.

Job autonomy, cognitive ability and job related skills influences job performance (Morgeson, Klinger and Hemingway, 2005). Employees with greater discretion in their work are more likely to expand their jobs beyond the job description. Job autonomy and constant feedback from supervisors are positively related to work engagement which in turn was found to influence performance (Bakker and Bal, 2010). The findings of these two 
studies should however be used cautiously as data was collected from very small and unrepresentative samples.

Empowering employees has also been found to improve performance (Meyerson \& Dewettinck, 2012). The study found that delegation, participatory management, encouragement and reward are positively related to organisational outcomes. However, this study used a sample based on one organisation and its findings may therefore not be used to make generalisation.

A strong correlation exists across different organisations between employee engagement and; customer loyalty, productivity and profitability, employee turnover, employee and customer safety incidences, absenteeism, shrinkage and defects (Harter, Schmidt, Schimidz, Killham, Angawal \& Plowman, 2013). These organisational outcomes were found to be very pronounced between the top performing and bottom performing organisations implying that the influence of engagement on business success is significant.

Wachira (2013) found that employee engagement influences organisational commitment while Kibui (2015) found that employee engagement affects talent retention. However, these two studies failed to link employee engagement with organisational performance a gap that the current study seeks to address.

\section{Organisational Commitment and Organisational Performance}

Normative and affective commitments have been found to be positively related to performance while the relationship with continuance commitment has been found to be negative (Khan, Ziaddin, Jam \& Ranay, 2010). Further, Dixit and Bhati (2012) found all the three types of commitment to be positively related to productivity. Lee and Chen (2013) found no relationship between job commitment and job attitude and between job attitude and service quality. Memari, Mahdieh and Marnani (2013) found positive relationship between employee commitment and organisational performance. However, employees may be committed to the job itself and not the organisation and hence the need to test the aggregate effect of organisational commitment on organisational performance rather than each indicator on its own.

Organisational commitment has been found to be based on the profession. Tolentino, (2013) for instance found that universities academic staffs have higher levels of affective and normative commitment while administrative staff have higher levels of continuance commitment. Affective commitment was found to be related to job performance among academic staff whereas this was not applicable to the administrative staff. This study was only limited to academic and administrative staff in a 
university setting and hence the need to have a study covering different organisations and professions to shed more light in to this relationship.

Agyemang and Ofei (2013) found that employee commitment leads to improved organisational performance by reducing turnover and increasing employee productivity. Further, the study found that levels of employee commitment and employee engagement are higher in the private sector than in the public service. The study however did not link the two constructs with organisational performance.

Most studies on organisational commitment have investigated its influence on employee job performance without connecting it to organisational outcomes. Further, the focus of most studies is on the direct relationship between organisational commitment and organisational performance with little attention being given to the mediating influence of organisational commitment on the relationship between other interventions and organisational performance. Therefore, this study sought to fill this apparent gap in literature.

\section{Research Methodology}

The study is anchored on positivism paradigm with data analysis being the basis for either rejecting or not rejecting the null hypotheses. To increase validity of the findings, the study used descriptive and explanatory research designs as recommended by (Saunders, Lewis \& Thornhill, 2007).

The study sample was selected using multi stage sampling. In the first stage, purposive sampling was done to select state corporations in research and training. In the second stage, Yamane (1967) formula of computing sample from finite population $\left(\mathrm{n}=\frac{N}{1+N(\mathrm{e}) 2}\right)$ was used to determine sample size which produced a sample of 378 respondents. The third stage involved random selection of respondents based on proportional representation.

Employee engagement was assesses using Utrecht Work Engagement Scale (UWES) which consisted of seventeen items (Schaufeli \& Bakker, 2003) while organisational commitment was assessed using Meyer and Allen (1990) organisational commitment model. These instruments have been widely used and confirmed as reliable. Testing the direct relationship was conducted using simple regression while casual steps as advocated by Baron and Kenny (1986) were adopted to test the mediation influence. The results were interpreted using adjusted $\mathrm{R}^{2}$ and corresponding $\mathrm{p}$-values.

\section{Research Findings}

The results obtained in relation to the direct relationship between employee engagement and performance of selected state corporations indicated that $\mathrm{R} 2$ had a score of 0.41 with a corresponding F-statistics of 
0.000. This implies that $41 \%$ of changes in organisational performance may be explained by employee engagement. The results indicated a beta coefficient of 0.64 with a corresponding p-value of 0.000 . This implies that a unit change in employee engagement results in 0.64 unit change in performance of state corporations in Kenya. On the basis of the regression results, the null hypothesis was rejected.

Testing the mediation influence involved conducting four casual steps as recommended Baron and Kenny (1986). After the test of the direct relationship, the second step involved regressing employee engagement on organisational commitment. The results obtained had an adjusted $\mathrm{R}^{2}$ of 0.28 with a corresponding F-statistics of 0.000 which implies that the relationship is significant. From these results, it may be concluded that $28 \%$ of changes in organisational commitment are explained by employee engagement. The relationship between organisational commitment and employee engagement is significant ( $\mathrm{p}$-value $<0.01)$. The beta value for employee engagement was 0.54 which implies that, holding all things constant, a unit change in employee engagement results in 0.54 unit change in organisational commitment.

The third step involved investigating the relationship between the organisational commitment and organisational performance. The result indicated that $33 \%$ of organisational performance is attributed to organisational commitment. The relationship between organisational commitment and organisational performance is significant ( $p$-value $<0.001$ ). Using the beta coefficient, the results indicate that a unit increase in organisational commitment would lead to .58 units of increase in organisational performance. These findings are similar to those of Khan et el (2010); Dixit and Bhati (2012) which found that organisational commitment influences organisational performance.

In the fourth step, organisational commitment was introduced in the regression as an explanatory variable and regressed with employee engagement on organisational performance to determine whether the influence is partial, complete or there is no influence on the relationship between employee engagement and performance of state corporations. The regression results indicated that $48 \%$ of changes in organisational performance may be explained by a combination of employee engagement and organisational commitment. The relationship is significant ( $\mathrm{p}$-value $<$ $0.01)$.

Employee engagement had a beta score of 0.47 with a corresponding $\mathrm{p}$-value of 0.000 (p-value $<0.01$ ) while organisational commitment had a beta score of 0.33 and a corresponding p-value of 0.000 ( $\mathrm{p}$-value $<0.01$ ). This indicates that a unit increase in employee engagement would lead to 0.47 unit increases in levels of performance in state corporations in Kenya 
while a unit increase in organisational commitment would increase performance by 0.33 units.

The result further indicates that the introduction of organisational commitment on the relationship between employee engagement and performance of state corporations' leads to an increase in Adjusted R squared scores from 0.41 to 0.48 . This implies that organisational commitment has a partial moderating influence on the relationship between employee engagement and performance of state corporations in Kenya. Consequently, the null hypothesis was rejected in favour of the alternate hypothesis.

Previous empirical studies have acknowledged the relationship between organisational commitment and organisational performance For instance, Field and Buitendawach (2011); Dixit and Bhati (2012); Memari, Mahdieh and Marnani (2013); Tolentino (2013); Agyemang and Ofei (2013; and Irefin and Mechanic (2014) all found a positive relationship between organisational commitment and organisational performance. On the other hand, Right Management (2009); Psychometric Canada Limited (2011); and Dajani (2015) all found positive relationship between the employee engagement ans organisational performance.

Organisational commitment has also been linked to organisational performance. For instance, Dixit and Bhati (2012); Tolentino (2013); and Albdour and Altarawneh (2014) found that employees' job performance and organisational performance are influenced by organisational commitment. Further, employee engagement has been linked to organisational commitment. Field and Buitendach (2011); Agyyemang and Ofei (2013) and Albdour and Altarawneh (2014) found strong evidence that employee engagement influence organisational commitment.

\section{Conclusion}

The study concludes that employee engagement is an important contributor to organisational performance. Therefore, employers should pay attention to recruiting employees with the necessary traits that are related to engagement and create conducive conditions at the work place that increases levels of engagement. In addition, organisational commitment is a critical ingredient in human resource management as it has a significant direct and indirect influence on organisational performance. Therefore, human resource practitioners should develop human resource policies that not only promote employee engagement but also deepen levels of organisational commitment if they hope to improve performance.

The study contributes to knowledge in the area of employee engagement and organisational performance in several ways. It was based on Kenya where there is scanty empirical research on influence of employee 
engagement and even the few studies conducted, they have not linked it to organisational performance. In addition, most previous empirical studies on the constructs are based on the private sector while little has been done in the public sector.

On a theoretical level, the current study contributes to empirical evidence that supports the social exchange theory by providing empirical support to the theory's preposition that mutually beneficial relationships at the work place results in a win-win situation. By providing employees with a challenging, secure and safe work environment, employers reap the benefits of engaged employees which in turn positively influences organisational performance.

\section{Recommendations for Further Research}

This study is subject to certain limitations. First, the study was cross sectional in nature as opposed to longitudinal analyses. Although a robust design was used to determine causal relationship between variables, cross sectional data does not achieve the same level of confidence as longitudinal analyses. It is recommended that future studies adopt a longitudinal approach.

The study focussed on influence of employee engagement and organisational commitment on organisational performance but did not investigate the antecedent of employee engagement. Future studies should include the antecedents of employee engagement to give a better understanding of the construct.

\section{References:}

1. Adcroft, A., Willis R. (2005). The (un)intended outcome of public sector performance measurement. International journal of public sector management, vol 18, issue 5, pp 386-400

2. Agyemang, C.B. \& Ofei, S.B. (2013). Employee work engagement and organisational commitment: A comparative study of private and public sector organisations in Ghana. European Journal of Innovation and Research, Vol. 1(4), 20-33

3. Albdour, A, \& Altarawneh, I. (2014). Employee engagement and organisational commitment: Evidence from Jordan. International Journal of Business, 19(2).

4. Albrecht, S., Bakker, A., Gruman, J., Macey, W. \& Saks, A. (2015). Employee engagement, human resource management practices and competitive advantage. Journal of Organisational Effectiveness, People and Performance, Vol. 2, pp. 7-35

5. Amangara, T., (2013). The effect of demographic characteristics on organisational commitment: A study of the sales persons in the soft 
drink industry in Nigeria. European Journal of Business and Management Vol. 5, No.18

6. Anastassiou, T. \& Doumpos, M. (2010). Multi performance evaluation of public enterprises; The case of Greece. Investigaciones Europeasde Direccióny Economía de la Empresa, Vol. 6, No. 3, pp 11-24

7. Bakker, A.B., Schaufeli, W.B., Leiter, M.P. \& Taris, T.W. (2008). Work engagement: An emerging concept in occupational health psychology. Work Stress 22, 187-200

8. Baron, R. \& Kenny, D., (1986). The moderator-mediator variable distinction in social psychological research; Conceptual, strategic and statistical considerations. Journal of Personality and Psychology, Vol. 51 No. 6, pp 1173-1182

9. Blau, P.M (1964). Exchange and power in social life. Wiley, New York

10. Brown, S., McHardy, R., McNabb, R. \& Taylor, K. (2011). Workplace performance, worker commitment and loyalty. Discussion paper series; IZA DP No. 5447

11. Chughatai, A. (2008). Impact of job involvement on in-role job performance and organisational citizenship behaviour. Research paper, Dublin City University.

12. Cropanzano, R. \& Mitchell, M. (2005). Social exchange theory: An interdisciplinary review. Journal of Management 31: 874

13. Das, K. \& Teng, S.(2002). A social exchange theory of strategic alliances in F. J. Contractor and P. Lorange (Eds). Cooperative Strategies and Alliances. Oxford: Elsevier Science Ltd. 439-460.

14. Dixit, V., \& Bhati, M., (2012). A study about employee commitment and its impact on sustained productivity in India's auto-component industry. European Journal of Business and Social Science Vol. 1, No.6, pp34-51

15. Economic Commission for Africa, (2010). Innovations and best practices in public sector reforms: The case of Civil Service in Ghana, Kenya, Nigeria and South Africa

16. Field, A. P. (2009). Discovering statistics using SPSS, $2^{\text {nd }}$ edition. London: Sage.

17. Field, L. K. \& Buitendach, J. H. (2011). Happiness, work engagement and organisational commitment of support staff at a tertiary educational institution in South Africa. South Africa Journal of Industrial Psychology, 37(1)

18. Globerman, S. \& Nielsen, B. (2007). Equity versus non-equity strategic alliances involving Danish firms: An empirical investigation 
of the relative importance of partner and host country determinants. Journal of International Management 13, 449-471.

19. Grants, A.M. (2008). The significance of task significance: Job performance effects, relational mechanisms and boundary conditions. Journal of Applied Psychology Vol. 93(1), 108-124

20. Irefin, P., \& Mechanic, M. (2014). Effect of employee commitment on organisational performance in Coca cola Nigeria Limited Maiduguli, Borno State. IOSR Journal of Humanities and Social Sciences Volume 19, Issue 3, pp 33-41

21. Khan, M., Ziauddin,. Jam, F., \& Ramay, M. (2010). The impact of organisational commitment on employee job performance. European Journal of Social Sciences Vol. 15, No. 3

22. Kobia, M., \& Mohammed, N. (2006). Kenyan experience with performance contracting. Africa Association for Public Administration and Management (AAPA\&M), Round table Conference, Arusha, Tanzania, 4-8 ${ }^{\text {th }}$ December 2006

23. Lee, C. \& Chen, C. (2013). Relationship between employee commitment and job attitude and its effect on service quality. American Journal of Industrial and Business Management, 3 pp 196308

24. Memari, N., Mahdiah, O. \& Marnani (2013). The impact of organisational commitment on employee job performance: A study of Meli Bank. International, Journal of Contemporary Research in Business Vol. 5 No.5

25. Metawie, M., Gilman, M. (2005). Problems with implementation of performance measurement systems in the public sector where performance is linked to pay: Literature drawn from United Kingdom. $3^{\text {rd }}$ Conference on performance measurement and management control.

26. Meyerson, G., \& Dewettinck, B. (2012). Effect of empowerment on employee performance. Advanced Research in Economics and management Science, Vol. 2.

27. Morgeson, F., Klinger, K. \& Hemingway, M., (2005). The importance of job autonomy, cognitive ability and job related skills for predicting role breadth and job performance. Journal of applied Psychology, Vol. 9, No.2 pp399-406.

28. Mulabe, J. (2009). Human resource strategic orientation, employees outcomes and performance of state corporations in Kenya. Unpublished PhD thesis. University of Nairobi.

29. Obong'o, S.O. (2009). Implementation of performance contracting in Kenya. International Public Management Review, Vol. 10(2) 
30. Psychometric Canada Limited (2011). Control, Opportunity and Leadership: A study of employee engagement in the Canadian workplace

31. Republic of Kenya (2013). Report of the Presidential Taskforce on Parastatal Reforms, Government Printer

32. Right Management Canada (2009). Maximizing organisational performance; Global benchmarking study. Right Management, Canada.

33. Robbins, S. (1991); Organizational behaviour; Concepts, controversies and applications ( $5^{\text {th }}$ edition). Prentice Hall Inc

34. Salamon, S. \& Robinson, S. (2011). Trust that binds: The impact of collective felt trust in organisational performance. Research paper, University of British Colombia.

35. Saunders, M., L, P. \& Thornhill, A. (2007). Research Methods for Business Students (4th ed.). Harlow: Prentice Hall Financial Times.

36. Smith, G. R. \& Markwick, C. (2009). Employee engagement: A critical review of current thinking. Institute of Employee Studies Report No. 469

37. Tolentino, R. (2013). Organisational commitment and job performance of the academic and administrative personnel. International journal of Information technology and Business Management Vol. 15 No.1

38. Usikalu, O., Ogunleye, A. \& Effion, J. (2015). Organisational trust, job satisfaction and performance among teachers in Eketi state, Nigeria. British Open Journal of Psychology Vol. No. 1 pp1-10.

39. Yamane, T. (1967). Statistics: An Introductory Analysis, $2^{\text {nd }}$ Edition. New York: Harper and Row 